\title{
European Union SHIPSAN ACT Joint Action: Preparedness for the response to Ebola virus disease in the maritime transport sector
}

V A Mouchtouri (mouchtourib@med.uth.gr) $)^{1,2}$, G Nichols $\mathbf{s}^{1,2,3,4}$

1. European Union SHIPSAN ACT Joint Action

2. Department of Hygiene and Epidemiology, University of Thessaly, Larissa, Greece

3. Gastrointestinal Emerging and Zoonotic Infections Centre for Infectious Disease Surveillance and Control, Public Health England, London, United Kingdom

4. University of Exeter, Exeter, United Kingdom

Mouchtouri VA, Nichols G. European Union SHIPSAN ACT Joint Action: Preparedness for the response to Ebola virus disease in the maritime transport sector. Euro Surveill. 2015;20(1):pii=20997. Available online: http://www.eurosurveillance.org/ViewArticle.aspx?Articleld=20997

The European Union (EU) SHIPSAN ACT Joint Action has published a 'Questions and Answers' (Q\&A) section about Ebola virus disease in the maritime transport sector on its website.

The aim of the Q\&A is to provide clarifications useful for public health authorities, for port workers and for the shipping industry with regards to:

- Personal protective equipment for port health officers going aboard a ship, which has come from an affected area, without having ill persons on board

- Response measures by competent authority when a ship arrives from an affected country with a traveller presenting clinical criteria compatible with Ebola virus disease

- Transportation of a patient, meeting the criteria for the person under investigation or probable case, from the ship to the medical facility

- Actions by the competent authority in the event of a patient meeting the criteria for the person under investigation or probable case on board a ship

- Actions by the competent authority in the event of a traveller on board a ship meeting the criteria for a confirmed case of Ebola virus disease

- Waste management (sewage) on ships

- Ships visiting ports in affected countries

- Recommendatio ns to the captain of a ship departing from affected areas and going to an EU port

- Plan for event management of a suspected case of EVD on board ships

- Recommendation for port-workers in EU ports, dealing with cargo from affected areas

An algorithm is also provided, outlining two response phases: (i) phase one describes the decision making of the public health competent authorities in response to an event of a suspected case of Ebola virus disease on board ships and (ii) phase two describes the response of public health competent authorities to an event of a confirmed case of Ebola virus disease on board ships.

The above information can be used by the competent authorities in the development of contingency plans according to the International Health Regulations [1] in conjunction with European Centre for Disease Prevention and Control [2] and World Health Organization [3] guidelines.

The EU SHIPSAN ACT is a European Joint Action funded by the European Commission under the Health Programme (2008-2013) [4]. It deals with the impact on maritime transport of health threats due to biological, chemical and radiological agents, including communicable diseases and supports the implementation of International Health Regulations 2005.

\section{References}

1. World Health Organization (WHO). International Health Regulations (2005). Second edition. Reprinted 2008. Geneva: WHO; 2008. Available from: www.who.int/ihr/9789241596664/ en/index.html

2. European Centre for Disease Prevention and Control. Public health management of persons having had contact with Ebola virus disease cases in the EU, 7 November 2014. Stockholm: ECDC, 2014. Available from: http://www.ecdc.europa.eu/ en/publications/Publications/ebola-public-health-contactmanagement-update-10-November.pdf

3. World Health Organization. Travel and transport risk assessment: Interim guidance for public health authorities and the transport sector. 2014. Available from: http://www.who. int/csr/resources/publications/ebola/travel-guidance/en/

4. European Union Joint Action SHIPSAN ACT. 'The impact on maritime transport of health threats due to biological, chemical and radiological agents, including communicable diseases'. [Accessed 22 Dec 2014]. Available from: www. shipsan.eu 